\title{
Dose Calculations for the Concrete Water Tunnels at 190-C Area, Hanford Site
}

by S. Kamboj and C. Yu

Environmental Assessment Division,

Argonne National Laboratory, 9700 South Cass Avenue, Argonne, lllinois 60439

January 1997

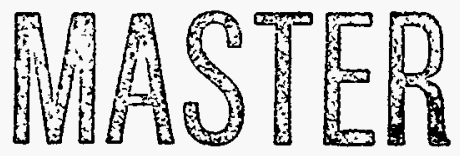

Work sponsored by United States Department of Energy, Office of Environmental Restoration, Washington, D.C., and Richland Operations Office, Richland, Washington

DISTRIBUTION OF THIS DOCUMETT IS URLMMTHED 
This report is printed on recycled paper. 


\section{DISCLAIMER}

Portions of this document may be illegible in electronic image products. Images are produced from the best available original document. 


\section{CONTENTS}

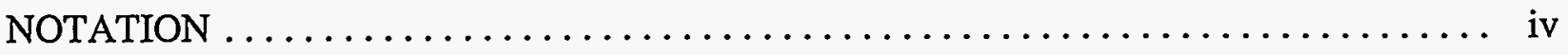

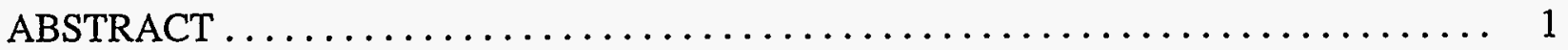

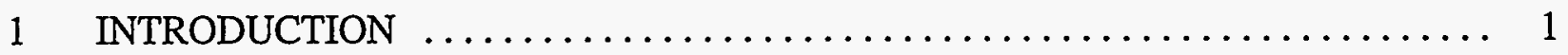

2 SCENARIO DEFINITIONS $\ldots \ldots \ldots \ldots \ldots \ldots \ldots \ldots \ldots \ldots \ldots \ldots \ldots \ldots \ldots \ldots \ldots$

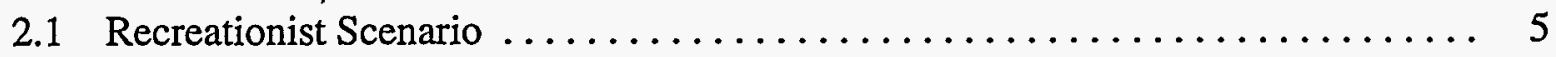

2.2 Maintenance Worker Scenario ........................... 5

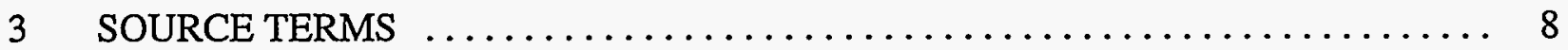

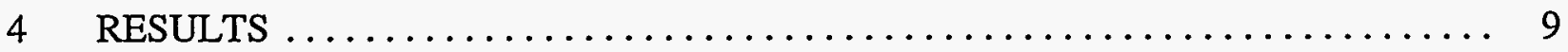

$5 \quad$ UNCERTAINTY ANALYSIS $\ldots \ldots \ldots \ldots \ldots \ldots \ldots \ldots \ldots \ldots \ldots \ldots \ldots \ldots \ldots \ldots \ldots$

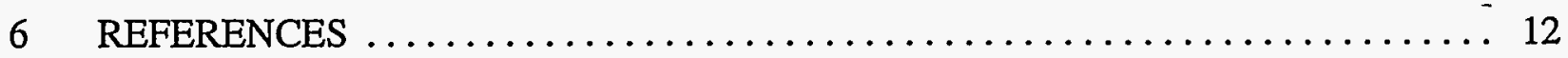

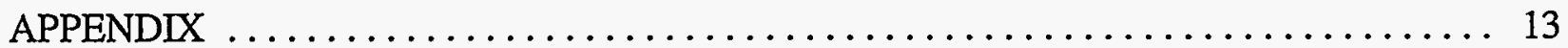

\section{FIGURES}

1 Location of Hanford Site, Richland, Washington $\ldots \ldots \ldots \ldots \ldots \ldots \ldots \ldots \ldots$

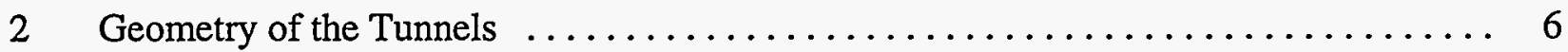

\section{TABLES}

1 Average Radionuclide Concentrations Used in the RESRAD-BUILD

Code for the Concrete Water Tunnels at the $190-\mathrm{C}$ Area . . . . . . . . . . . . . . 8

2 Summary of the Potential Maximum Dose Rates for the Recreationist

Scenario at Four Receptor Locations inside the Tunnel .................. 9

3 Summary of the Potential Maximum Dose Rates for the Maintenance Worker Scenario at Four Receptor Locations inside the Tunnel $\ldots \ldots \ldots \ldots \ldots$

A.1 Parameters Used in the RESRAD-BUILD Computer Code to Calculate the Dose from a Surface-Contaminated Concrete Tunnel for the Recreationist and Maintenance Worker Scenarios 


\section{NOTATION}

The following is a list of the acronyms, initialisms, and abbreviations (including units of measure) used in this document. Some acronyms used only in tables or equations are defined in the respective tables or equations.

\section{ACRONYMS, INITIALISMS, AND ABBREVIATIONS}

$\begin{array}{ll}\text { A-P } & \text { anterior-posterior } \\ \text { DOE } & \text { U.S. Department of Energy } \\ \text { P-A } & \text { posterior-anterior } \\ \text { RESRAD } & \text { residual radioactive material guideline computer code }\end{array}$

UNITS OF MEASURE
$\begin{array}{ll}\mathrm{cm} & \text { centimeter(s) } \\ \mathrm{d} & \text { day(s) } \\ \mathrm{g} & \text { gram(s) } \\ \mathrm{h} & \text { hour(s) } \\ \mathrm{L} & \text { liter(s) } \\ \mathrm{m} & \text { meter(s) } \\ \mathrm{m}^{2} & \text { square meter(s) } \\ \mathrm{m}^{3} & \text { cubic meter(s) } \\ \mathrm{mrem} & \text { milliroentgen(s) equivalent man } \\ \mathrm{pCi} & \text { picocurie(s) } \\ \mathrm{s} & \text { second(s) } \\ \mathrm{wk} & \text { week(s) } \\ \mathrm{yr} & \text { year(s) }\end{array}$




\title{
DOSE CALCULATIONS FOR THE CONCRETE WATER TUNNELS AT 190-C AREA, HANFORD SITE
}

by

\author{
S. Kamboj and C. Yu
}

\begin{abstract}
The RESRAD-BUILD code was used to calculate the radiological dose from the contaminated concrete water tunnels at the 190-C Area at the Hanford Site. Two exposure scenarios, recreationist and maintenance worker, were considered. A residential scenario was not considered because the material was assumed to be left intact (i.e., the concrete would not be rubbleized because the location would not be suitable for construction of a house). The recreationist was assumed to use the tunnel for 8 hours per day for 1 week as an overnight shelter. The maintenance worker was assumed to spend 20 hours per year working in the tunnel. Six exposure pathways were considered in calculating the dose. Three external exposure pathways involved penetrating radiation emitted directly from the contaminated tunnel floor, emitted from radioactive particulates deposited on the tunnel floor, and resulting from submersion in airborne radioactive particulates. Three internal exposure pathways involved inhalation of airborne radioactive particulates; inadvertent direct ingestion of removable, contaminated material on the tunnel floor; and inadvertent indirect ingestion of airborne particulates deposited on the tunnel floor. The gradual removal of surface contamination over time and the ingrowth of decay products were considered in calculating the dose at different times. The maximum doses were estimated to be $1.5 \mathrm{mrem} / \mathrm{yr}$ for the recreationist and $0.34 \mathrm{mrem} / \mathrm{yr}$ for the maintenance worker.
\end{abstract}

\section{INTRODUCTION}

The Hanford Site, acquired in 1943 , is a $1,450-\mathrm{km}^{2}$ reservation owned by the U.S. Government and administered by the U.S. Department of Energy (DOE), Richland Operations Office. It is located in the Pasco Basin along the Columbia River in southeastern Washington State and covers portions of Benton, Grant, Franklin, and Adams Counties (Figure 1). The Yakima River 


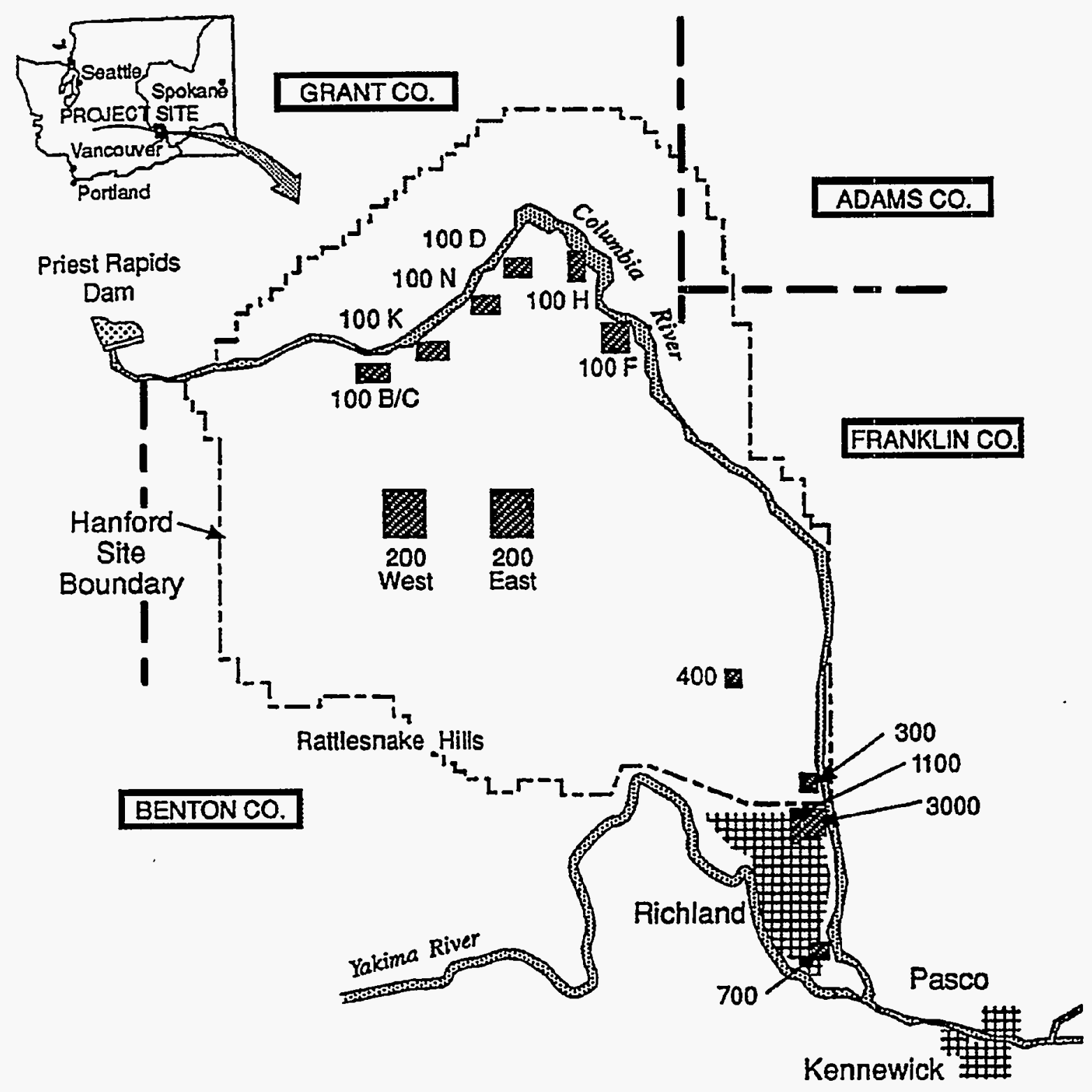

Note: The 600 Area consists of all portions of the Hanford Site not othenwise designated.

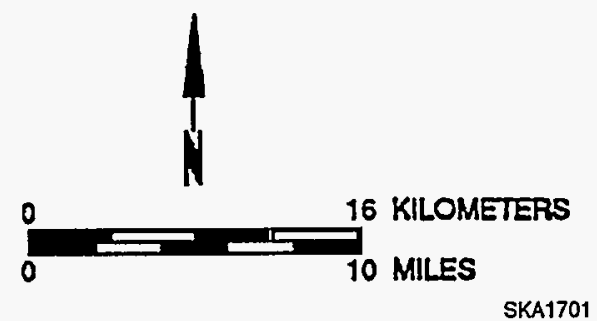

FIGURE 1 Location of Hanford Site, Richland, Washington 
runs along part of the southern boundary and joins the Columbia River downstream from the city of Richland (Figure 1).

The Hanford Site was initially dedicated to producing plutonium for national defense and managing the resulting wastes. In later years, programs were diversified to include conducting research for advanced reactors, renewable energy technologies, waste disposal technologies, and cleanup of contamination from past practices. The site's current mission involves waste management, environmental restoration, scientific research, and technology development.

The major operational areas on the site include (1) the 100 Areas on the south shore of the Columbia River, (2) the 200-West and 200-East Areas on a plateau, (3) the 300 Area located just north of the city of Richland, (4) the 400 Area northwest of the 300 Area, and (5) the 600 Area, which includes all of the Hanford Site not occupied by the 100, 200, 300, and 400 Areas (Figure 1).

Water tunnels are located in the 100 Areas. The 100 Areas include nine nuclear reactors, associated facilities, and structures. The underground tunnels connect the process pumphouse at $190-\mathrm{C}$ to the 105-C reactor. During reactor operations, the floors of the water tunnels became contaminated with activation products, fission products, and transuranic elements. The presence of these radionuclides could result in radiation doses to individuals working in these tunnels or using the tunnels as shelter. Such doses may result from exposure to penetrating radiation from the contaminated material, inhalation of contaminated airborne particulates, or incidental ingestion of contaminated material on tunnel surfaces.

The RESRAD-BUILD code version 1.50 (Yu et al. 1994) was used to calculate the dose from residual radionuclide contamination on the floors of the concrete water tunnels at the 190-C Area at the Hanford Site. Specific radionuclides included cobalt-60, strontium-90, cesium-137, europium-152, plutonium-239, and americium-241. Two exposure scenarios were considered: tunnel maintenance and use of the tunnel for shelter. A residential scenario was not considered because the material was assumed to be left intact (i.e., the concrete would not be rubbleized because the location would not be suitable for building a house). The tunnels are like hollow pipes that cannot be used as the base for a foundation. If someone were to attempt to excavate the area to a depth of $15 \mathrm{ft}$, that individual would encounter the roof of the tunnel before encountering any tunnel contamination. That person would then most likely cease excavation and move to a place without any underlying concrete. 


\section{SCENARIO DEFINITIONS}

Two scenarios were selected for calculating the dose from residual radioactivity. A recreationist scenario (DOE 1995) was used to assess exposure to external gamma (at a close distance of $15 \mathrm{~cm}$ ) and particulate emissions from the tunnel surfaces, as well as the contributions from the ingrowth of decay products. A maintenance scenario was used to assess exposure over a shorter time (external exposure was calculated at a distance of $1 \mathrm{~m}$ from the contaminated floor).

Six exposure pathways were considered in calculating the dose (Yu et al. 1994):

1. External exposure to penetrating radiation emitted directly from the contamination on the tunnel floor;

2. External exposure to penetrating radiation emitted from radioactive particulates deposited on the tunnel floor;

3. External exposure to penetrating radiation due to submersion in airborne radioactive particulates;

4. Internal exposure due to inhalation of airborne radioactive particulates;

5. Internal exposure due to inadvertent direct ingestion of radioactive material in removable, contaminated material on the tunnel floor; and

6. Internal exposure due to inadvertent indirect ingestion of airborne radioactive particulates deposited on the tunnel floor.

A detailed discussion of the models used to assess the doses from these pathways is given in the RESRAD-BUILD user's manual (Yu et al. 1994).

Many uncertainties may exist in the input values for the parameters used in the model formulations. Most of the parameter values used in the two scenarios are RESRAD-BUILD defaults (Yu et al. 1994). Exceptions included the source concentrations, occupancy, inhalation and direct ingestion rates, ventilation rate, emission rates, and exposure times. Each scenario is described below, along with the key parameter assumptions. A complete list of parameter values used in each scenario is provided in Table A.1 of the appendix. 


\subsection{RECREATIONIST SCENARIO}

The recreationist was assumed to use a tunnel as an overnight shelter for $8 \mathrm{~h} / \mathrm{d}$ for $1 \mathrm{wk}$. The tunnel was modeled as one room with a floor area of $425 \mathrm{~m}^{2}$ and a $3.2-\mathrm{m}$ ceiling height. The surface of the floor was assumed to be uniformly contaminated, and $98.6 \%$ of the contamination was assumed to be fixed (Denham 1996). The remaining contamination (1.4\%) was assumed to be removable from the surface at a constant rate over a 10 -yr period.

Of the radionuclides that gradually erode from contaminated surfaces, $100 \%$ were assumed to become airborne and instantaneously mix in the tunnel volume. This airborne component was assumed to be exhausted from the tunnel at an air exchange rate of $0.2 / \mathrm{h}$ (the tunnels are underground and would have very little air exchange) and deposited on the floor at a rate of $0.01 \mathrm{~m} / \mathrm{s}$ ( $\mathrm{Yu}$ et al. 1994). Any deposited dust was assumed to be resuspended in the tunnel air at a rate of $5 \times 10^{-7} / \mathrm{s}$ (Yu et al. 1994).

While in a tunnel, the recreationist was assumed to breathe contaminated air at a rate of $1.2 \mathrm{~m}^{3} / \mathrm{h}$ (International Commission on Radiological Protection 1975) and ingest contaminated dust deposited on surfaces at a rate of $0.0001 \mathrm{~m}^{2} / \mathrm{h}$ ( $\mathrm{Yu}$ et al. 1994). Direct ingestion from the contaminated surfaces was assumed to be negligible because the recreationist was using the tunnel as an overnight shelter and was not involved in any activity to remove the contamination.

The external exposure component of the dose for the recreationist was calculated at a point $15 \mathrm{~cm}$ above the floor. Four hypothetical receptor locations in a tunnel were selected to study dose variations within the tunnel: 25, 50,110, and $130 \mathrm{~m}$ from the front end of section A-A (Figure 2). The floor in the tunnel was modeled as a number of disk sources. Section A-A was divided into 31 sources, each with an area of $11.2 \mathrm{~m}^{2}(3.35 \times 3.35 \mathrm{~m})$; transition section $\mathrm{B}-\mathrm{B}$ was divided into 9 sources, each with an area of $7.53 \mathrm{~m}^{2}(2.74 \times 2.74 \mathrm{~m})$; and section $\mathrm{C}-\mathrm{C}$ was divided into 5 sources, each with an area of $11.2 \mathrm{~m}^{2}(3.35 \times 3.35 \mathrm{~m})$. The RESRAD-BUILD computer code can handle 10 sources and 10 receptor locations in a single run. Therefore, five different runs were performed, and the dose values were added to calculate the total dose for each receptor. For the recreationist, an anterior-posterior (A-P) source-receptor geometry (Yu et al. 1994) was used.

\subsection{MAINTENANCE WORKER SCENARIO}

A maintenance worker was assumed to spend $20 \mathrm{~h} / \mathrm{yr}$ repairing a tunnel. During this work, all of the contamination on the floor was assumed to be removed at a constant rate during the year. Because greater mechanical action is likely to occur during maintenance activity, the fraction of respirable particulates that is generated and becomes airborne during the worker's stay was assumed to be 10 times higher than the fraction released during the recreationist scenario. 


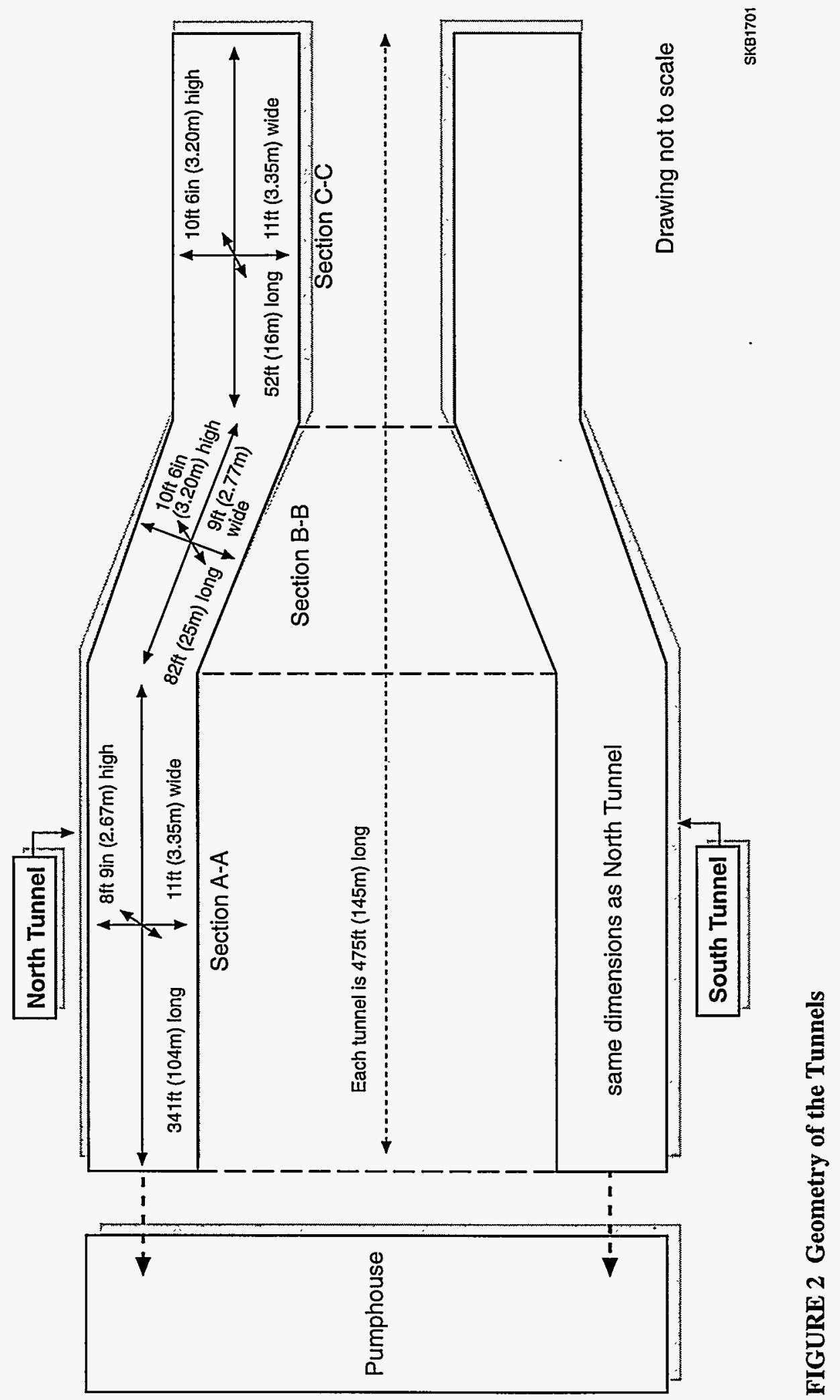


Only $10 \%$ of the contamination was assumed to become airborne and instantaneously mixed in the tunnel volume. As it was in the recreationist scenario, this airborne component was assumed to be removed from the tunnel at an air exchange rate of $0.2 / \mathrm{h}$ and to have a deposition rate of $0.01 \mathrm{~m} / \mathrm{s}$. Deposited dust was assumed to be resuspended in the tunnel air at a rate of $5 \times 10^{-7} / \mathrm{s}$ (Yu et al. 1994).

The external exposure component of the dose was calculated at a point $1 \mathrm{~m}$ above the center of the floor for the maintenance worker (receptor locations were the same as those used in the recreationist scenario). The floor in the tunnel was modeled as the same number of disk sources as those modeled in the recreationist scenario. The maintenance worker was assumed to be irradiated uniformly from all directions. Therefore, external gamma dose conversion factors for a rotational source-receptor geometry ( $Y u$ et al. 1994) rather than an A-P geometry were used in this scenario.

While in the tunnel, the worker was assumed to breathe contaminated air at a rate of $1.2 \mathrm{~m}^{3} / \mathrm{h}$, ingest contaminated material directly from the contaminated surfaces at a rate of $1 \times 10^{-6} / \mathrm{h}$ (Yu et al. 1994), and ingest contaminated dust deposited on surfaces at a rate of $0.0001 \mathrm{~m}^{2} / \mathrm{h}$. 


\section{SOURCE TERMS}

The source concentrations used in the RESRAD-BUILD computer code were based on tunnel survey data and separate smear samples that were analyzed for gamma, beta, and alpha emitters (Denham 1996). The data at different locations in the tunnels were normally distributed; therefore, average contamination values and removable release fractions were used. The average removable fraction was $1.4 \%$ of the total concentration. The contamination levels were not significantly different in the two tunnels; therefore, data from both tunnels were used for calculating the average concentration. Table 1 gives the average radionuclide concentrations used in RESRADBUILD.

TABLE 1 Average Radionuclide Concentrations Used in the RESRAD-BUILD Code for the Concrete Water Tunnels at the 190-C Area

\begin{tabular}{lcc}
\hline \multicolumn{1}{c}{ Radionuclide } & Distribution $(\%)$ & Concentration $\left(\mathrm{pCi} / \mathrm{m}^{2}\right)$ \\
\hline Cobalt-60 & 0.42 & 30,400 \\
Cesium-137 & 46 & $3,330,000$ \\
Europium-152 & 0.21 & 15,200 \\
Strontium-90 & 53 & $3,840,000$ \\
Americium-241 & 0.03 & 2,170 \\
Plutonium-239 & 0.3 & 21,700 \\
\hline
\end{tabular}




\section{RESULTS}

The RESRAD-BUILD code was used to calculate the potential radiation doses for each exposure scenario. The doses were calculated at time zero and after $10 \mathrm{yr}$ for the recreationist scenario and only at time zero for the maintenance worker scenario. Radioactive decay and ingrowth were considered in calculating the maximum dose rates. The various parameters used for this analysis are listed in Table A.1 in the appendix. The calculated maximum dose rates for the two scenarios and four receptors are presented in Tables 2 and 3, respectively.

For both scenarios, the maximum calculated dose rates $(1.5 \mathrm{mrem} / \mathrm{yr}$ for the recreationist and $0.34 \mathrm{mrem} / \mathrm{yr}$ for the maintenance worker) did not exceed the DOE $(1990,1992)$ dose limit of $100 \mathrm{mrem} / \mathrm{yr}$. For both scenarios, the maximum dose would occur at time zero at receptor location 2 , which is in the middle of section A-A of a tunnel. For both scenarios, external exposure would be the dominant pathway, followed by dust inhalation in the recreationist scenario and ingestion in the maintenance worker scenario. For the recreationist, external exposure would contribute $\sim 85 \%$ to the total dose. For the maintenance worker, external exposure and direct ingestion would contribute $\sim 44 \%$ and $\sim 34 \%$, respectively, to the total dose.

TABLE 2 Summary of the Potential Maximum Dose Rates (mrem/yr) for the Recreationist Scenario at Four Receptor Locations inside the Tunnel

\begin{tabular}{lcccc}
\hline \multicolumn{1}{c}{ Pathway } & Receptor 1 & Receptor 2 & Receptor 3 & Receptor 4 \\
\hline External & 1.14 & 1.29 & 1.11 & 1.12 \\
Deposition & $4.00 \times 10^{-3}$ & $4.00 \times 10^{-3}$ & $4.00 \times 10^{-3}$ & $4.00 \times 10^{-3}$ \\
Immersion & $1.84 \times 10^{-5}$ & $1.84 \times 10^{-5}$ & $1.84 \times 10^{-5}$ & $1.84 \times 10^{-5}$ \\
Inhalation & $1.98 \times 10^{-1}$ & $1.98 \times 10^{-1}$ & $1.98 \times 10^{-1}$ & $1.98 \times 10^{-1}$ \\
Ingestion & $2.34 \times 10^{-2}$ & $2.34 \times 10^{-2}$ & $2.34 \times 10^{-2}$ & $2.34 \times 10^{-2}$ \\
Total & 1.37 & 1.52 & 1.34 & 1.35 \\
\hline
\end{tabular}


TABLE 3 Summary of the Potential Maximum Dose Rates (mrem/yr) for the Maintenance Worker Scenario at Four Receptor Locations inside the Tunnel

\begin{tabular}{lllll}
\hline \multicolumn{1}{c}{ Pathway } & Receptor 1 & Receptor 2 & Receptor 3 & Receptor 4 \\
\hline External & $1.46 \times 10^{-1}$ & $1.50 \times 10^{-1}$ & $1.31 \times 10^{-1}$ & $1.43 \times 10^{-1}$ \\
Deposition & $1.43 \times 10^{-3}$ & $1.43 \times 10^{-3}$ & $1.43 \times 10^{-3}$ & $1.43 \times 10^{-3}$ \\
Immersion & $7.21 \times 10^{-4}$ & $7.21 \times 10^{-4}$ & $7.21 \times 10^{-4}$ & $7.21 \times 10^{-4}$ \\
Inhalation & $7.06 \times 10^{-2}$ & $7.06 \times 10^{-2}$ & $7.06 \times 10^{-2}$ & $7.06 \times 10^{-2}$ \\
Ingestion & $1.16 \times 10^{-1}$ & $1.16 \times 10^{-1}$ & $1.16 \times 10^{-1}$ & $1.16 \times 10^{-1}$ \\
Total & $3.35 \times 10^{-1}$ & $3.38 \times 10^{-1}$ & $3.19 \times 10^{-1}$ & $3.32 \times 10^{-1}$ \\
\hline
\end{tabular}




\section{UNCERTAINTY ANALYSIS}

As mentioned in Section 2, considerable uncertainty existed in the estimated dose. Average source concentrations in the tunnels were used for the dose calculations, but if a person were to spend more time near a hot spot (a small, isolated, highly contaminated area), he or she would be likely to receive a dose much higher than the estimated doses.

It was assumed that the air exchange rate was $0.2 / \mathrm{h}$ and that the maximum dose would occur inside the tunnel at receptor location 2 . In actuality, the recreationist would likely stay near the tunnel entrance, which would reduce the external dose; moreover, the air exchange rate would be higher near the entrance, which would also reduce the contribution from other pathways.

For the recreationist scenario, the most conservative A-P geometry dose conversion factors were used. For a person sleeping on his or her back, a posterior-anterior (P-A) geometry (Yu et al. 1994) would be appropriate; therefore, the estimated external dose could be as much as $20 \%$ higher. Conservative inhalation and ingestion rates were also used in this scenario, because the recreationist was assumed to use the tunnel for shelter and thus would not be involved in any vigorous activity.

For the maintenance worker scenario, it was assumed that the person was directly ingesting contaminated material at the rate of $1 \times 10^{-6} / \mathrm{h}$. The worker would not actually be in direct contact with the entire source at a given time; therefore, this assumption was very conservative. 


\section{REFERENCES}

Denham, D.H., 1996, memorandum from Denham (Hanford Site, Richland, Wash.) to C. Yu (Argonne National Laboratory, Argonne, Ill.), June.

DOE (see U.S. Department of Energy).

International Commission on Radiological Protection, 1975, Report of the Task Group on Reference Man, ICRP Publication 23, Pergamon Press, New York, N.Y.

U.S. Department of Energy, 1990, Radiation Protection of the Public and the Environment, DOE Order 5400.5, Feb.

U.S. Department of Energy, 1992, Radiological Control Manual, Assistant Secretary for Environment, Safety and Health, Washington, D.C., June.

U.S. Department of Energy, 1995, Hanford Site Risk Assessment Methodology, DOE/RL-91-45, Rev. 3, Richland, Wash., May.

Yu, C., et al., 1994, RESRAD-BUILD: A Computer Model for Analyzing the Radiological Doses Resulting from the Remediation and Occupancy of Buildings Contaminated with Radioactive Material, ANL/EAD/LD-3, Argonne National Laboratory, Argonne, Ill., Nov. 